\title{
Milk Quality Characteristics of Native Southern Yellow and South Anatolian Red between Early and Late lactation
}

\section{Aylin Celile Oluk ${ }^{\mathbf{a}}$}

Ministry of Food Agriculture and Livestock, Eastern Mediterranean Agriculture Research Institute, 01321 Adana, Turkey

\begin{tabular}{l|l}
\hline A R T I C L E I N F O & A B S T R A C T \\
\hline Research Article & $\begin{array}{l}\text { South Anatolian Red (SAR) and Native Southern Yellow (NSY) cattle are commonly reared in } \\
\text { the southern region of Turkey. Although physical characteristics of these significant races that are } \\
\text { under protection are similar, it is determined in various studies that they have different racial } \\
\text { characteristics. The goal of this study is to evaluate lactation characteristics of two different breeds } \\
\text { in same region. It is observed that NSY milk has higher dry matter (\%), fat (\%), protein (\%), } \\
\left.\text { lactose (\%), total saturated and unsaturated fatty acids (g 100g } \mathrm{g}^{-1}\right) \text { ratios than SAR milk. In the } \\
\text { study, eight volatiles (indoles, ketones, terpenes, aromatic hydrocarbons, esters, carboxylic acids, } \\
\text { aldehydes, alcohols) of the cattle types are researched and analyzed and they are compared during } \\
\text { lactation periods. At the end of lactation, esters and carboxylic acids increased in NSY milk, while } \\
\text { Accepted : }: 18 / 01 / 2019 \\
\text { ketones and aldehydes in SAR milk increased. It is seen that alcohols are the most abundant } \\
\text { volatile components found in milk of cattle. On the other hand, it is observed that lactation stages, } \\
\text { forage type and botanical diversity affect milk flavor and quality. }\end{array}$ \\
$\begin{array}{l}\text { Keywords: } \\
\text { Lactose } \\
\text { Indoles } \\
\text { Ketones }\end{array}$ &
\end{tabular}

Terpenes

Lactation period

\section{Introduction}

Today, it is known that there are totally 897 cattle breeds worldwide; Turkey has 23 native cattle breeds, but 15 breeds of them has become extinct in the last 50 years, 6 breeds of them are currently under risk of extinction and only 2 breeds (East Anatolian Red and Native Black) are commonly reared in Turkey (Soysal, 2010). Native Southern Yellow (NSY) lives in Taurus and Amonos Mountains along the Mediterranean shore while the South Anatolian Red (SAR) is located in the area between Mediterranean (Mersin) and South Anatolia (Sanliurfa) in Turkey. The scientific name of these cattle types is Bos Taurus, and they are used for meat and milk.

The estimated population of these cattle was 4000 until recently, but it is believed that the number of these cattle has rapidly decreased to 2000 and SAR it is faced with the risk of extinction. Short body, long narrow head and short or sometimes rudimentary horns are the characteristics of this race. The race is well adapted to heat and tolerant to parasites (Yilmaz et al., 2012).
NSY is a breed of historical importance, but it has begun to diminish due to decreasing numbers of farmers and its inability to adapt to regions except its centre of origin in the southeastern provinces bordering Syria and the Mediterranean. NSY have the ability to graze in mountainous regions. This breed which has brown feather is extremely resistant to diseases, parasites and adverse environmental conditions (Soysal, 2010).

In general, Turkey has large animal genetic resource in terms of natural life and livestock genetic resources. However, our native animal genetic resources are now faced with extinction because of uncontrolled and unconscious cross-breeding with the exotic breeds (Unalan, 2007). The milk yield of local breeds is lower than the yield of culture cattle.

Despite the fact that there are many studies on the variety characteristics of these breeds, there is no the data about milk characteristics. In this study, we have investigated the milk quality characteristics in early and late lactation periods of NSY and SAR milks. 


\section{Materials and Methods}

In this study, milks of NSY and SAR were collected from cattle in two separate regions (Bagdatl1-Feke and Hilvan) in two different periods. Bagdatl is a village in the District of Feke, Adana Province, ( $37^{\circ} 54^{\prime} 52.4520^{\prime \prime}$ and $\left.35^{\circ} 50^{\prime} 44.3256^{\prime \prime}\right)$, located at $981 \mathrm{~m}$ altitude. Hilvan is geographically in the south Anatolian province in Turkey ( $37^{\circ} 35^{\prime} 20.5656^{\prime \prime}$ and $\left.38^{\circ} 57^{\prime} 30.4632^{\prime \prime}\right)$ and located at 598 $\mathrm{m}$ altitude. Milk samples of early lactation were collected in the period between April 10 and 20 in Feke and between April 20 and 30 in Hilvan. Late lactation samples were taken between the $15^{\text {th }}$ and $20^{\text {th }}$ of October. Milk samples were collected between April and October from 20 NSY and 22 SAR at regular intervals of 7 days, for a total of three samples/head. The milk samples were then mixed together into two cumulative samples for each period, divided into two parts and immediately frozen at -18 degrees. Milk compositions were analysed by using an infrared milk analyser (Milkoscan FT 120, FOSS Electric, Hillerød, Denmark) for solids, fat, protein, total saturated and unsaturated milk content. Milk samples were agitated at $2000 \mathrm{rpm}$ for $10 \mathrm{~s}$ (IKA Microstar 7.5 control, Germany) and incubated in $40^{\circ} \mathrm{C}$ water-bath prior to the NIR measurements. A transmittance cell (thickness: $1 \mathrm{~mm}$ ) was used. The spectral data were analysed by 1SI (InfraSoft International, Port Matilda, PAl software. The values of absorbance at each wavelength and the concentrations of each parameters obtained by the standard methods

Determined volatiles were analysed with the static head space solid phase microextraction (SPME) method by using gas chromatography-mass spectrometry system (Shimadzu Corporation, Kyoto, Japan) as described by Hayaloglu et al., (2007). A sample of milk (40 mL) was weighed into a $100 \mathrm{~mL}$ vial and mixed $10 \mathrm{~g}$. $\mathrm{NaCl}$, followed by $10 \mu \mathrm{L}$ of internal standard containing $81 \mathrm{mg} / \mathrm{kg}$ of 2 methyl-3-heptanone in methanol (Sigma-Aldrich Co. USA) and conditioned at $40^{\circ} \mathrm{C}$ for $30 \mathrm{~min}$ before the analysis. The volatiles was carried out using a solventless extraction technique. Essentially, extraction is achieved by

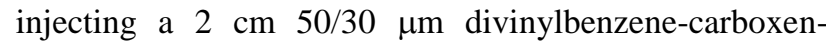
polydimethylsiloxane (DVB/CAR/PDMS) fiber (Supelco, Bellefonte, PA, USA) into the vial and heating at $60^{\circ} \mathrm{C}$ for $30 \mathrm{~min}$. The fiber was positioned at 3.0 scale units in each run. A Shimadzu GC-2010 gas chromatography - QP-2010 mass spectrometry system (Shimadzu Corporation, Kyoto, Japan) was run in splitless mode for desorption of the extracted volatiles. The desorption of volatile components was achieved by heating $250^{\circ} \mathrm{C}$ in 2 min with helium as the carrier gas at a flow rate of $1.0 \mathrm{~mL} / \mathrm{min}$. The analytical column was DB-Wax column $60 \mathrm{~m} \times 0.25 \mathrm{~mm} \times 0.25 \mathrm{um}$ (J\&W Scientific, Folsom, CA, USA). GC conditions were oven initial temperature $40^{\circ} \mathrm{C}$, hold for $2 \mathrm{~min}$., then programmed to $70^{\circ} \mathrm{C}$ at a rate of $5^{\circ} \mathrm{C}$ per min; hold for 1 min and finally ramped to $240^{\circ} \mathrm{C}$ at $10^{\circ} \mathrm{C}$ per min with a 30 min. final isotherm. The mass spectrometer was set to record at 33 to $450 \mathrm{amu}$ (threshold 1,000) at a sampling rate of $1.11 \mathrm{scans} / \mathrm{s}$. The volatile compounds were identified by calculation of the retention index (RI) of each compound, using an $n$-alkane series $\left(\mathrm{C}_{8}\right.$ to $\left.\mathrm{C}_{20}\right)$ under the same conditions. The compounds were tentatively identified by Wiley 7 (7th edition) and NIST/EPA/NIH 02 mass spectral library. The volatiles of milk samples were used to confirm with thirty authentic standard compounds (Sigma chemical Co., St. Louis, MO) The RI values were also compared with those described in the literature determined under the same conditions for matching the compounds. The results were calculated by the comparison of the peak area of the internal standard and the unknown compounds. Each compound was expressed as $\mu \mathrm{g} 100 \mathrm{~g}^{-1}$ of sample.

SPSS 16.0 package program for Windows (SPSS Inc., Chicago, IL, USA) was used for analysis of variance (ANOVA) and Duncan's multiple comparison test was carried out in order to determine significant differences $(\mathrm{P}<0.05)$ between treatments. Multi-variable statistical analysis of sensory analysis was implemented by using Numerical Taxonomy and Multivariate Analysis System (NTSYS), Version 2.1 developed by Rolf, (1993). Each experiment was repeated minimum three times.

\section{Results and Discussion}

It is determined that there is significant difference between dry matter, fat, protein, lactose, unsaturated fat and saturated fat ratios between NSY and SAR $(\mathrm{P}<0.05)$. It is observed that dry matter, fat, protein, unsaturated and saturated fat ratios increased while lactose decreased in NSY during lactation period (Table 1). The cause of the decline is less glucose in the mammary glands as a result of reduced blood flow due to stress conditions (Chen et al., 2017). Composition of protein, fat and lactose was variable during lactation. Tsioulpas et al., (2007) found that fat, protein and lactose levels increased during lactation period, while Auldist et al., (1998) found that lactose decreased in late lactation period. Lactose content of NSY milk is higher than that of SAR milk at early lactation. Higher levels of lactose content probably contributed to high heat stability in NSY milk.

Table 1 Comparison of milk composition between NSY and SAR

\begin{tabular}{l|cccc}
\multicolumn{1}{c|}{ Variables } & $\begin{array}{c}\text { Early* } \\
\text { Lactation }\end{array}$ & $\begin{array}{c}\text { Early } \mathrm{z} \\
\text { Lactation }\end{array}$ & $\begin{array}{c}\text { Late* } \\
\text { Lactation }\end{array}$ & $\begin{array}{c}\text { Late } \mathrm{z} \\
\text { Lactation }\end{array}$ \\
\hline Dry matter (\%) & $9.03 \pm 1.14^{\mathrm{a}}$ & $8.2 \mathrm{~b} \pm 0.1^{\mathrm{b}}$ & $9.96 \pm 0.33^{\mathrm{a}}$ & $8.30 \pm 0.01^{\mathrm{b}}$ \\
Fat $(\%)$ & $3.26 \pm 0.5^{\mathrm{c}}$ & $3.54 \pm 0.01^{\mathrm{b}}$ & $3.69 \pm 0.15^{\mathrm{b}}$ & $4.03 \pm 0.02^{\mathrm{a}}$ \\
Protein $(\%)$ & $3.34 \pm 0.38^{\mathrm{b}}$ & $2.86 \pm 0.1^{\mathrm{c}}$ & $4.52 \pm 0.47^{\mathrm{a}}$ & $2.97 \pm 0.15^{\mathrm{c}}$ \\
Lactose (\%) & $4.86 \pm 0.82^{\mathrm{a}}$ & $4.60 \pm 0.1^{\mathrm{b}}$ & $4.63 \pm 0.18^{\mathrm{b}}$ & $4.62 \pm 0.11^{\mathrm{b}}$ \\
Total unsaturated fatty acid $\left({\left.\mathrm{g} 100 \mathrm{~g}^{-1}\right)}^{\left.\text {botal saturated fatty acid g100g } \mathrm{g}^{-1}\right)}\right.$ & $1.31 \pm 0.78^{\mathrm{c}}$ & $2.52 \pm 0.1^{\mathrm{b}}$ & $3.01 \pm 0.29^{\mathrm{a}}$ & $2.62 \pm 0.20^{\mathrm{b}}$ \\
Total monounsaturated fatty acid $\left(\mathrm{g}^{\mathrm{b}} 100 \mathrm{~g}^{-1}\right)$ & $1.79 \pm 0.56^{\mathrm{b}}$ & $0.86 \pm 0.1^{\mathrm{d}}$ & $3.61 \pm 0.14^{\mathrm{a}}$ & $1.04 \pm 0.14^{\mathrm{c}}$ \\
Total polyunsaturated fatty acid $\left(\mathrm{g} 100 \mathrm{~g}^{-1}\right)$ & $1.19 \pm 0.97^{\mathrm{c}}$ & $1.70 \pm 0.1^{\mathrm{b}}$ & $2.38 \pm 0.68^{\mathrm{a}}$ & $2.24 \pm 0.11^{\mathrm{a}}$ \\
\hline
\end{tabular}

*Means \pm SD within a row with no common superscript differ $(\mathrm{P}<0.05)$. ${ }^{*} \mathrm{NYS}$, $\mathrm{e}$ SAR 
Table 2 Changes in volatiles $\left(\mu \mathrm{g} 100 \mathrm{~g}^{-1}\right.$, mean SD) during lactation period $(\mathrm{df}=9)$ in NSY and SAR milk*

\begin{tabular}{|c|c|c|c|c|c|}
\hline Compounds & RI & $\begin{array}{c}\text { NSY } \\
\text { early lactation } \\
\end{array}$ & $\begin{array}{c}\text { NSY } \\
\text { late lactation }\end{array}$ & $\begin{array}{c}\text { SAR } \\
\text { early lactation } \\
\end{array}$ & $\begin{array}{c}\text { SAR } \\
\text { late lactation }\end{array}$ \\
\hline & \multicolumn{5}{|c|}{ Indoles } \\
\hline 3 methylindole(skatole) & 1070 & $5.492 \pm 0.04^{b}$ & $3.846 \pm 0.063^{c}$ & $6.742 \pm 0.074^{\mathrm{a}}$ & $5.175 \pm 0.075^{\mathrm{b}}$ \\
\hline 2-amino-3-carbethoxy-6- pyridine & 1299 & $1.204 \pm 0.03^{b}$ & nd & $6.208 \pm 0.08^{\mathrm{a}}$ & $0.373 \pm 0.02^{\mathrm{c}}$ \\
\hline N-ethyl-1,3-dithioisoindoline & 1617 & nd & nd & $0.053 \pm 0.01^{b}$ & $1.018 \pm 0.01^{\mathrm{a}}$ \\
\hline 2-3-N-phenylimino indole & 1085 & nd & nd & $0.060 \pm 0.01$ & nd \\
\hline \multirow[t]{2}{*}{ 1H-Indole } & 1257 & $0.262 \pm 0.02^{\mathrm{b}}$ & $0.166 \pm 0.01^{\mathrm{c}}$ & $0.422 \pm 0.03^{\mathrm{a}}$ & nd \\
\hline & \multicolumn{5}{|c|}{ Ketones } \\
\hline 2-heptanone & 1175 & $0.474 \pm 0.07^{\mathrm{c}}$ & $0.214 \pm 0.02^{\mathrm{d}}$ & $0.797 \pm 0.10^{\mathrm{a}}$ & $0.585 \pm 0.03^{b}$ \\
\hline 2-octanone & 964 & $0.856 \pm 0.06^{\mathrm{b}}$ & $1.042 \pm 0.03^{\mathrm{a}}$ & $0.750 \pm 0.02^{\mathrm{b}}$ & $1.041 \pm 0.01^{\mathrm{a}}$ \\
\hline 4-nonanone & 1076 & $0.858 \pm 0.06^{\mathrm{b}}$ & $0.736 \pm 0.08^{c}$ & $0.413 \pm 0.06^{\mathrm{d}}$ & $0.932 \mathrm{a} \pm 0.07$ \\
\hline 3-buten-2-one & 1014 & $0.040 \pm 0.01^{\mathrm{a}}$ & nd & $0.112 \pm 0.06^{\mathrm{a}}$ & nd \\
\hline \multirow[t]{2}{*}{ 2-methylindanone } & 1118 & $0.052 \pm 0.01^{\mathrm{a}}$ & nd & $0.035 \pm 0.02^{\mathrm{b}}$ & nd \\
\hline & \multicolumn{5}{|c|}{ Terpenes } \\
\hline$\alpha$ pinene & 936 & $1.708 \pm 0.60^{\mathrm{b}}$ & $1.584 \pm 0.04^{\mathrm{c}}$ & $2.37 \pm 0.015^{\mathrm{a}}$ & $1.192 \pm 0.08^{\mathrm{d}}$ \\
\hline dl-limonene & 1025 & $3.238 \pm 0.07^{\mathrm{a}}$ & $1.830 \pm 0.04^{\mathrm{c}}$ & $3.195 \pm 0.02^{\mathrm{a}}$ & $2.633 \pm 0.02^{\mathrm{b}}$ \\
\hline$\beta$-phellandiene & 1002 & $1.896 \pm 0.04^{\mathrm{a}}$ & $1.792 \pm 0.06^{\mathrm{b}}$ & $1.792 \pm 0.05^{\mathrm{b}}$ & $1.095 \pm 0.08^{c}$ \\
\hline Cymene & 1013 & $2.648 \pm 0.06^{\mathrm{a}}$ & $0.174 \pm 0.01^{\mathrm{c}}$ & $1.605 \pm 0.06^{\mathrm{b}}$ & $0.620 \pm 0.02^{\mathrm{d}}$ \\
\hline n-terpene & 1107 & $0.108 \pm 0.01^{\mathrm{d}}$ & $0.308 \pm 0.01^{\mathrm{c}}$ & $0.670 \pm 0.01^{\mathrm{a}}$ & $0.495 \pm 0.01^{\mathrm{b}}$ \\
\hline$\beta$ pinene & 978 & nd & nd & $0.053 \pm 0.03^{\mathrm{b}}$ & $1.018 \pm 0.02^{\mathrm{a}}$ \\
\hline \multirow[t]{2}{*}{$\alpha$-Iron } & 1191 & $0.128 \pm 0.02^{\mathrm{a}}$ & nd & $0.087 \pm 0.01^{\mathrm{b}}$ & nd \\
\hline & \multicolumn{5}{|c|}{ Aromatic hydrocarbon } \\
\hline Styrene & 1273 & $2.632 \pm 0.012^{\mathrm{a}}$ & $1.108 \pm 0.024^{b}$ & $2.330 \pm 0.05^{\mathrm{a}}$ & $1.050 \pm 0.05^{\mathrm{b}}$ \\
\hline 1-ethenyl-4-ethyl- benzene & 1132 & $1.378 \pm 0.06^{\mathrm{a}}$ & $0.340 \pm 0.02^{\mathrm{d}}$ & $1.152 \pm 0.07^{\mathrm{b}}$ & $0.452 \pm 0.07^{\mathrm{c}}$ \\
\hline Benzene & 1226 & $0.166 \pm 0.05^{\mathrm{b}}$ & $0.612 \pm 0.01^{\mathrm{a}}$ & nd & nd \\
\hline 1-decene & 1240 & nd & $0.116 \pm 0.01^{\mathrm{a}}$ & $0.050 \pm 0.01^{\mathrm{b}}$ & nd \\
\hline 1-tridecene & 1557 & nd & $0.102 \pm 0.02$ & nd & nd \\
\hline 2-tetradecene & 1387 & nd & $0.238 \pm 0.04$ & nd & nd \\
\hline 1-pentadecene & 1298 & nd & $0.048 \pm 0.03$ & nd & nd \\
\hline Hexadecene & 1875 & nd & $0.142 \pm 0.02$ & nd & nd \\
\hline 1.3-benzothiadiazole & 1072 & $1.172 \pm 0.03^{\mathrm{a}}$ & $1.004 \pm 0.06^{\mathrm{b}}$ & $0.630 \pm 0.01^{\mathrm{c}}$ & nd \\
\hline 3-O-(trimethylsilyl)-5.7.3'.4'-tetra o-methyl quercetin & 1079 & $0.452 \pm 0.03^{\mathrm{a}}$ & $0.384 \pm 0.04^{\mathrm{b}}$ & $0.083 \pm 0.03^{\mathrm{d}}$ & $0.133 \pm 0.03^{c}$ \\
\hline 1-anthracenamine & 1565 & $0.250 \pm 0.03^{\mathrm{b}}$ & $0.352 \pm 0.01^{\mathrm{a}}$ & $0.051 \pm 0.06^{\mathrm{c}}$ & nd \\
\hline Benzenesulfonyl chloride & 1150 & $0.252 \pm 0.01^{\mathrm{a}}$ & $0.234 \pm 0.02^{\mathrm{a}}$ & nd & $0.148 \pm 0.03^{b}$ \\
\hline 9H-carbazole & 1010 & $0.070 \pm 0.01^{\mathrm{b}}$ & nd & $0.280 \pm 0.01^{\mathrm{a}}$ & nd \\
\hline 1.3-diethenyl benzene & 843 & $0.272 \pm 0.02^{\mathrm{b}}$ & nd & $0.728 \pm 0.02^{\mathrm{a}}$ & nd \\
\hline Methoxy-phenyl- /oxime & 1115 & $0.614 \pm 0.01^{\mathrm{b}}$ & $0.642 \pm 0.02^{\mathrm{b}}$ & $0.922 \pm 0.06^{\mathrm{a}}$ & nd \\
\hline \multirow[t]{2}{*}{ 5-Ethylindan } & 1177 & $0.064 \pm 0.01^{\mathrm{b}}$ & nd & $0.022 \pm 0.03^{\mathrm{c}}$ & $0.115 \pm 0.01^{\mathrm{a}}$ \\
\hline & \multicolumn{5}{|c|}{ Esters } \\
\hline Hexanoic acid ethyl ester & 905 & nd & $0.212 \pm 0.01^{\mathrm{a}}$ & $0.150 \pm 0.02^{\mathrm{b}}$ & nd \\
\hline 2-5-thiazolyl thyocyanate & 1306 & nd & $0.140 \pm 0.01$ & $0.171 \pm 0.06$ & nd \\
\hline Decanoic acid ethyl ester & 1823 & nd & nd & $0.910 \pm 0.06^{\mathrm{a}}$ & $0.065 \pm 0.01^{\mathrm{b}}$ \\
\hline \multirow[t]{2}{*}{ Dodecanoic acid ethyl ester } & 1557 & nd & nd & $0.120 \pm 0.01$ & nd \\
\hline & \multicolumn{5}{|c|}{ Carbocxylic acid } \\
\hline Acetic acid & 1467 & nd & $0.352 \pm 0.02^{\mathrm{a}}$ & $0.053 \pm 0.01^{\mathrm{c}}$ & $0.238 \pm 0.01^{\mathrm{b}}$ \\
\hline Butanoic acid & 1646 & nd & $0.500 \pm 0.01$ & nd & nd \\
\hline Benzoik asit & 1160 & $0.378 \pm 0.09 a$ & $0.306 \pm 0.01^{\mathrm{a}}$ & $0.385 \pm 0.02^{\mathrm{a}}$ & $0.187 \pm 0.07^{\mathrm{b}}$ \\
\hline Octanoic acid & 2083 & nd & $0.324 \pm 0.05^{b}$ & $0.403 \pm 0.04^{\mathrm{a}}$ & nd \\
\hline Hexadecanoic acid (palmitic acid) & 1951 & nd & nd & nd & $0.950 \pm 0.01$ \\
\hline Capric acid & 1809 & nd & $0.750 \pm 0.01^{\mathrm{b}}$ & $1.938 \pm 0.05^{\mathrm{a}}$ & $0.368 \pm 0.02^{\mathrm{c}}$ \\
\hline Octadecanoic acid & 2182 & nd & nd & nd & $0.465 \pm 0.01$ \\
\hline Oleic acid & 1999 & nd & nd & nd & $0.347 \pm 0.03$ \\
\hline Tetradecanoic acid (miristic acid) & 1748 & nd & $0.392 \pm 0.02$ & nd & nd \\
\hline \multirow[t]{2}{*}{ Lauric acid } & 1554 & nd & $0.250 \pm 0.01$ & $0.203 \pm 0.02$ & nd \\
\hline & \multicolumn{5}{|c|}{ Aldehydes } \\
\hline Benzaldehyde & 941 & $0.482 \pm 0.03^{\mathrm{a}}$ & nd & $0.248 \pm 0.02^{\mathrm{b}}$ & $0.155 \pm 0.02^{\mathrm{c}}$ \\
\hline \multirow[t]{2}{*}{ 2-Propenal } & 1419 & $0.062 \pm 0.01^{\mathrm{b}}$ & nd & $0.265 \pm 0.02^{\mathrm{a}}$ & nd \\
\hline & & & Alcoh & & \\
\hline Ethanol & 931 & $19.974 \pm 0.80^{c}$ & $22.856 \pm 0.90^{\mathrm{b}}$ & $24.153 \pm 0.80^{\mathrm{a}}$ & $24.855 \pm 0.11^{\mathrm{a}}$ \\
\hline 2-octanol & 981 & $21.240 \pm 0.70^{\mathrm{b}}$ & $23.408 \pm 0.90^{\mathrm{a}}$ & $16.06 \pm 0.70^{\mathrm{d}}$ & $19.367 \pm 0.70^{c}$ \\
\hline 4-nonanol & 1076 & $30.718 \pm 0.39^{b}$ & $32.294 \pm 0.89^{\mathrm{a}}$ & $22.155 \pm 0.07^{c}$ & $30.172 \pm 0.02^{b}$ \\
\hline Cyclopropyl carbinol & 1148 & nd & nd & nd & $0.816 \pm 0.04$ \\
\hline Cyclobutanol & 1252 & nd & $0.420 \pm 0.01^{\mathrm{b}}$ & $0.805 \pm 0.02^{\mathrm{a}}$ & $0.375 \pm 0.01^{\mathrm{c}}$ \\
\hline 2-furanmethanol & 981 & nd & $0.128 \pm 0.01^{\mathrm{b}}$ & nd & $0.283 \pm 0.03^{\mathrm{a}}$ \\
\hline Fluoren-9-ol & 1108 & $0.076 \pm 0.01$ & nd & nd & nd \\
\hline
\end{tabular}

*Means \pm SD within a row with no common superscript differ $(\mathrm{P}<0.05)$, nd: not detected. $\mathrm{RI}=$ retention index using alkane series $(\mathrm{C} 8$ to $\mathrm{C} 20)$ under the same chromatographic conditions 

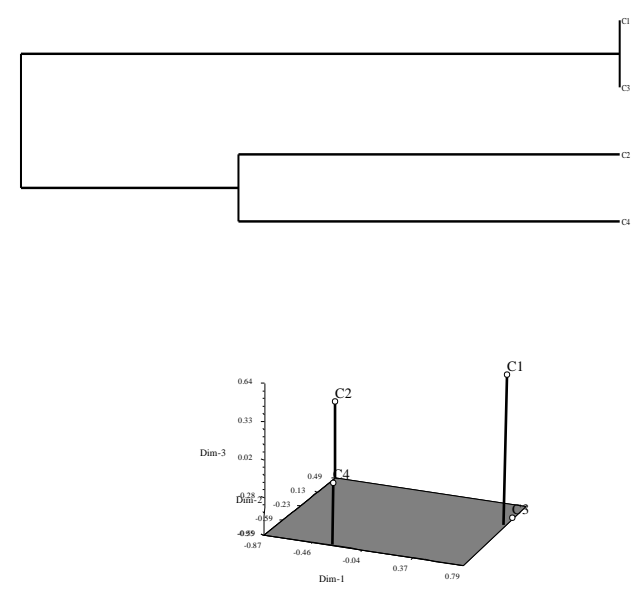

Figure 1 Milk composition dendrograms and PCA graphs of NSY and SAR milks. C1: SAR milk early lactation, C2 : NSY milk early lactation, C3: SAR milk late lactation, C4: NSY milk late lactation

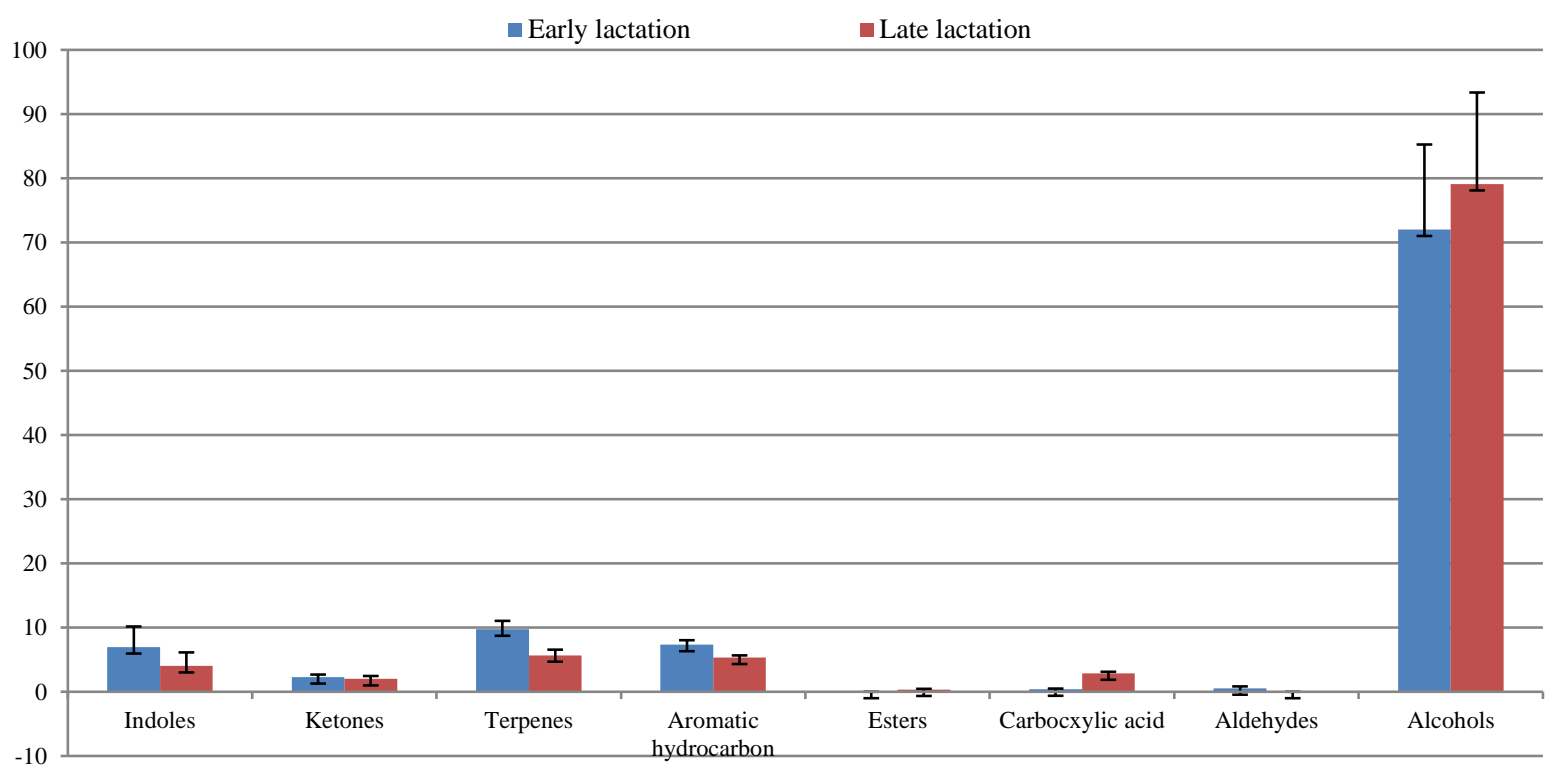

Figure 2 Change of volatiles during lactation period in NSY milk

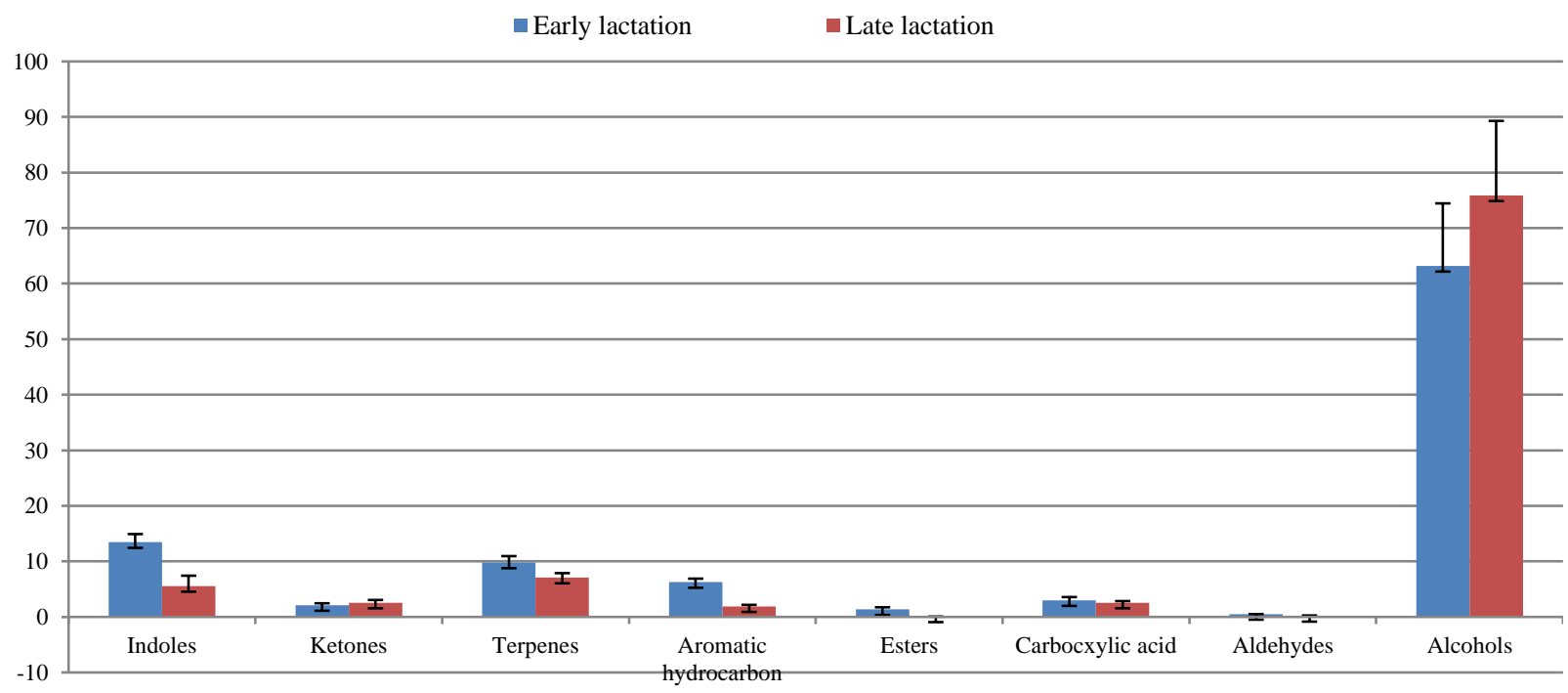

Figure 3 Change of volatiles during lactation period in SAR milk 
During lactation period, all quality components increased except total polyunsaturated fatty acid in SAR. Temperatures in April and October in Feke ranged from 12.8 to $10.6^{\circ} \mathrm{C}$, while the change in Hilvan was between $20.0^{\circ} \mathrm{C}$ and $26.9^{\circ} \mathrm{C}$. The milk composition may have positively affected the fatty acid as the temperature change in Feke was lower than Hilvan. Increasing temperature increased the fat ratio but negatively affected polyunsaturated fatty acid content. These differences in milk quality may explain differences among breeds and feed and changing climate conditions (Bale et al., 2014). NSY milk contains higher proportions of total saturated fatty acid and lower proportions of total unsaturated fatty acid because of extensive lipolysis and biohydrogenation of dietary unsaturated fatty acids and synthesis of saturated fatty acid within the mammary gland (Kliem and Shingfield, 2016).

Computer-assisted multivariate analysis of the milk composition was carried out and; when the distance obtained in the graphic carried out in terms of multivariate technique used for analyzing milk composition of NSY and SAR in different lactation time is analyzed, it is seen that the effect is significant (Fig 1). According to dendogram and PCA graphic, NSY and SAR milks were in different groups.

\section{Volatiles}

32 compounds were detected during early lactation period in SAR milk, while 49 compounds were found in NSY milk. During lactation period, alcohols, esters, carboxylic acids increased while other compounds decreased (Fig 2). Increasing PUFA concentration in milk fat may have increased the concentration of their oxidation and degradation products. In this regard, the corresponding alcohols under reducing conditions may be converted to straight-chain aldehydes and ketones at the double bounds by $\beta$-oxidation (Nursten, 1997).

At the beginning of the lactation of SAR there were 40 volatile component contents while there were 48 volatiles at the end of lactation (Fig 3). On the other hand, indoles, terpenes, aromatic hydrocarbons, esters and carboxylic acids decreased during whole lactation period.

The amount of indole in SAR milk was found to be higher in both periods when compared with the amount in NSY milk (Table 2). The amount of 3-methylindole (skatole) in SAR was higher than NSY milk in both lactation periods (6.742 to $\left.5.175 \mu \mathrm{g} 100 \mathrm{~g}^{-1}\right)$. Skatole is derived from tryptophan degradation. Researchers have found high amounts of skatole in the milks of grazing animals (Prache et al., 2005).

The ketones are formed by decarboxylation of saturated fatty acids (Amador-Espejo et al., 2017). During the lactation period, the amount of ketones in SAR increased while the amount of ketones in NSY decreased. A total of five different ketones were identified in the analyzed samples. During lactation period, 2 heptanones decreased and 2 nonanes increased in the milk of both breeds.

Seven terpenes were identified in SAR milk, while six compounds were observed in NSY milk. At the end of lactation, the amounts of dl-limonene, cymene and nterpene in SAR milk were higher than the amounts of them in NSY milk. It is expected that there will be more terpenes in the milk of pasture-type animals (Villeneuve et al., 2013). The amount of dl-limonene was found to be higher in SAR than in NSY milk at the end of lactation. This compound is found in raw milk, and it is related with forage (Amador-Espejo et al., 2017). The amount of terpenes in SAR milk is higher than terpenes in NSY milk; this is resulted from the fact that there are Centaurea depressa, Centaurea polypodiifolia, Crepis aspera species in Hilvan. The researcher indicates that the compounds of sesquiterpenes are found in Centaurea species varieties (Reyhan et al., 2004).

16 aromatic hydrocarbons were determined in NSY milk while 11 compounds were observed in SAR milk. These compounds diminished at the end of lactation. Styrene and 1-ethenyl-4-ethyl- benzenes are the most common aromatic hydrocarbons. Aromatic hydrocarbons are secondary compounds formed auto-oxidation of free fatty acids when hydroperoxides change to more stable forms (He et al., 2013). Methoxy-phenyl-oxime was found in both lactation periods in NSY milk. Methoxy-phenyloxime is an aromatic hydrocarbon was related to antitumor substances formed by the activity of myxobacteria (Xu et al., 2011).

SAR milk contains 4 ester compounds. These are hexanoic acid, ethyl ester, 2-5-thiazolyl thyocyanate, decanoic acid ethyle ester, dodecanoic acid and ethyl ester. Decanoic acid ethyl esters are the most abundant esters in SAR milk.

In the lactation period, the amount of carboxylic acid in NSY milk increased while the amount in SAR milk decreased. Short-chain fatty acids such as butanoic and benzoic acid are produced by the degradation of triglycerides; these acids can be easily attacked by peroxides which cause rancid or oxidized flavors (He et al., 2013).

Aldehydes significantly affect milk flavor. At the end of lactation; the aldehyde concentration in the NSY milk decreased while the concentration in SAR increased. It was determined that benzaldehyde, known as linear aldehydes, is highest in NSY milk during early lactation. Benzaldehyde is commonly formed by auto-oxidation of unsaturated fatty acids and the hydroperoxides decomposed by heat and light and may be increase during storage spontaneously (Amador-Espejo et al., 2017).

Most abundant volatiles in both breed milks are alcohols. Ethanol, 2-octanol and 4- nonanol have increased during lactation period. The aromatic note associated with ethanol is dry or dusty (González-Martín et al., 2014). There were significant differences between NSY and SAR milks alcohol ratios $(\mathrm{p}<0.05)$. The formation of alcohols in milk can be due to the reduction of the correspondent aldehydes (He et al., 2013). 2-furanmethanol was found at the late lactation in both milk types. Secondary alcohols such as 2-Octanol and 2 furanmethanol are related with sweet, fruity and floral aromas (González-Martín et al., 2014). Ethanol can arise from silages, which can affect alcohol concentration in milk indirectly, via rumen metabolism and directly by way of its presence in particular silage odours (Toso et al., 2002). High alcohol content in milk shows that breeds have silage in their diet. 


\section{Conclusion}

NSY cows live in mountainous regions and have characteristically smaller body size. The milk quality of low-yielding NSY cows is better than the quality of SAR milk. The volatile profile of NSY and SAR milks significantly affected as they feed with different botanical composition during lactation period. Milk quality is considerably affected by the lactation period. The natural variations in heat stability of milk are significant for production of milk powder, pasteurized and UHT milk. The higher levels of protein and fat found in NSY milks can be resulted in higher cheese yields. On the other hand, different properties in milk may be important for cheese production. Milk with lower casein ratio than fat was more suitable for the bloomy rind cheeses. Therefore, selecting the milk on the basis of different breeds could probably maximize the milk value in specific cheese products.

\section{References}

Amador-Espejo, GG, Gallardo-Chacon JJ, Juan B, Trujillo AJ. 2017. Effect of ultra-high-pressure homogenization at moderate inlet temperatures on volatile profile of milk. J. Food Process Eng. 40(5): e12548. DOI:10.1111/jfpe.12548

Auldist MJ, Walsh BJ, Thomson NA. 1998. Seasonal and lactational influences on bovine milk composition in New Zealand. J. Dairy Res.65: 401-411. PMID:9718493

Baul S, Cziszter LT, Acatincai S, Gavojdian D, Erina S, Marcu A, Buzamat G, Răducan GG. 2014. Seasonal Influences on Milk Yield and Composition Dynamics during a Normal Lactation in Dairy Cows: Milk Yield, Fat and Protein Percentage. J. Anim. Sci. Biotechnol. 47 (1): 260-265.

Chen B, Grandison AS, Lewis MJ 2017. Best use for milk - A review. II - Effect of physiological, husbandry and seasonal factors on the physicochemical properties of bovine milk. Int. J.Dairy Technol. 70(2): 155-164. DOI:10.1111/1471-0307.12355

González-Martín I, Hernández-Hierro JM, González-Pérez C, Revilla I, Vivar-Quintana A, Lobos Ortega I. 2014. Potential of near infrared spectroscopy for the analysis of volatile components in cheeses. LWT - Food Sci. Technol. 55: 666673. DOI: $10.1016 /$ j.lwt.2013.10.008

Hayaloglu AA, Cakmakci S, Brechany EY, Deegan KC, McSweeney PLH. 2007. Microbiology, biochemistry and volatile composition of Tulum cheese ripened in goat's skin or plastic bags. J. Dairy Sci. 90:1102-1121. DOI: 10.3168/jds.S0022-0302(07)71597-7
He J, Vazquez-Landaverde P, Qian MC, Eskin NAM. 2013. Offflavors in milk. In Biochemistry of foods (3rd ed., Vol. 1) San Diego. Elsevier. ISBN: 9780444885586.

Kliem KE, Shingfiel KJ. 2016. Manipulation of milk fatty acid composition in lactating cows: Opportunities and challenges. Eur. J. Lipid Sci. Technol. 118: 1661-1683. DOI: 10.1002/ ejlt. 201400543

Nursten HE. 1997. The flavour of milk and dairy products: I. Milk of different kinds, milk powder, butter and cream. Int. J.Dairy Technol. 50:48-56. DOI: 10.1111/j.1471-0307.1997. tb01735.x

Prache S, Cornu A, Berdagu'e JL, Priolo A. 2005. Traceability of animal feeding diet in the meat and milk of small ruminants. Small Rumin. Res. 59: 157-168. DOI:10.1017/ S1751731110002296

Reyhan A, Kupeli E, Ergun F. 2004. The biological activity of Centaurea L. species. Gazi University Journal of Science, 17(4): 149-164. ISSN 1303-9709

Rolf FJ. 1993. NTSYS-pc, Numerical taxonomy and multivariate analysis system, version 1.18. New York, Exeter, Setauket. pp:44.

Soysal MI. 2010. Evcil hayvan genetik kaynaklari çeşitliliği tehdit altinda. Accessed 21.05.2018, available at http://site.mynet.com/genkaynaklari/Hazirlar/gen kaynaklari korunmali.html (In Turkish).

Toso B, Procida G, Stefanon B. 2002. Determination of volatile compounds in cows' milk using headspace GC-MS. J. Dairy Res. 69: 569-577. DOI:10.017 /S0022029902005782

Tsioulpas A, Lewis MJ, Grandison AS. 2007. Changes in physical properties of bovine milk from the colostrums period to early lactation. J. Dairy Sci. 90: 5012-5017. DOI: $10.3168 /$ jds.2007-0192

Unalan A. 2007. Gen kaynaklarini koruma projesi (Kilis sigiri: Güney Anadolu Kirmizisi). Accessed 19.03.2018 available at http://www.tarim.gov.tr/Files/Files/e_kutuphane/gkk pkilis sigiri.pdf (In Turkish).

Xu F, Tao WY, Sun J. 2011. Identification of volatile compounds released by myxobacteria Sorangium cellulosum AHB103-1. Afr. J. Microbiol. Res. 5(4): 353-358. DOI:10.5897/AJMR10.718.

Villeneuve MP, Lebeuf Y, Gervais R, Tremblay GF, Vuillemard JC, Fortin J, Chouinard, PY. 2013. Milk volatile organic compounds and fatty acid profile in cows fed timothy as hay, pasture, or silage. J. Dariy Sci. 96: 7181-7194 DOI:10.3168/jds.2013-6785

Yilmaz O, Akin O, Metin Yener S, Ertugrul M, Wilson RT. 2012. The domestic livestock resources of Turkey: cattle local breeds and types and their conservation status. Anim. Genet. Resour. 50: 65-73. DOI:10.1017/S2078633613000015 